\title{
ECTOPIC LIVER IN GALL BLADDER: A CASE REPORT
}

\author{
Abhilash S1, Karthik K², Keisham Lokendra Singh ${ }^{3}$, S. Ranita Devi, G. S. Moirangthem ${ }^{5}$
}

\section{HOW TO CITE THIS ARTICLE:}

Abhilash S, Karthik K, Keisham Lokendra Singh, S. Ranita Devi, G. S. Moirangthem. "Ectopic Liver in Gall Bladder: A Case Report". Journal of Evolution of Medical and Dental Sciences 2015; Vol. 4, Issue 09, January 29;

Page: 1574-1577, DOI: $10.14260 /$ jemds/2015/220

ABSTRACT: Ectopic liver (EL) is a rare developmental anomaly in which the liver tissue is situated outside the liver and has no hepatic connection. The real incidence of EL attached to the gallbladder wall is difficult to assess but is reportedly $0.24-0.47 \%$ of the population though as with other sites, most of the cases of EL attached to the gallbladder are diagnosed at laparotomy, laparoscopy or during an autopsy. Hepatobiliary Imino- Diacetic Acid (HIDA) scan, besides ultrasonography and computerized tomography, may be helpful in diagnosis. Colour Doppler ultrasound or angiography may demonstrate a feeding vessel.

KEYWORDS: Autopsy, Ectopic Liver, Gall Bladder.

INTRODUCTION: Ectopic liver (EL) is a rare developmental anomaly in which the liver tissue is situated outside the liver and has no hepatic connection. ${ }^{1}$

The real incidence of EL attached to the gallbladder wall is difficult to assess but is reportedly $0.24-0.47 \%$ of the population though as with other sites, most of the cases of EL attached to the gallbladder are diagnosed at laparotomy, laparoscopy or during an autopsy. ${ }^{2}$

In 1940 in a review of 5500 autopsies, only $0.05 \%$ had EL and in only three cases was this attached to the wall of the gallbladder. ${ }^{3}$

More recently, a review of 1060 laparoscopic procedures found EL attached to the gallbladder wall in three patients $(0.28 \%){ }^{4}$

CASE REPORT: A 45 year old woman with a 6 month history of bilary colic and an episode of acute cholecystitis was referred for surgery. A previous abdominal ultrasound scan showed normally distended gall bladder with multiple hyperechoic lesions casting acoustic shadows (Figure 1).

The patient was posted for laparoscopic cholecystectomy after making preoperative diagnosis of cholelithiasis. A serosal encapsulated brownish mass, attached to the serosa of the gallbladder body by a fibrous pedicle was noted intraoperatively (Figure 2). The mass was removed en-bloc with the gallbladder through the umbilical port-site. On gross examination, a grey brown tissue resembling that of a normal liver attached to the serosal surface of the gall bladder measuring $1 \times 0.8 \mathrm{cms}$ was noted (Figure 3 ). The microscopic examination revealed features of chronic inflammation of the gallbladder with ectopic liver tissue with a well preserved architecture and few areas of feathery degeneration.

DISCUSSION: In the fourth week of intrauterine life, with the formation of the duodenum, the hepatic bud arises as an evagination of endoderm from the ventral angle between the foregut and the yolk sac. This hepatic diverticulum extends into the septum transversum, where it enlarges and divides into two parts: the larger cranial portion (Pans hepatica), which further divides to form the liver cells and intrahepatic biliary apparatus of the right and left hepatic lobes, and the smaller caudal portion (Pars cystica), which gives rise to the gallbladder and the cystic duct. ${ }^{5}$ 
Several theories have been proposed to explain the development of ectopic liver at different sites: development of an accessory lobe of the liver with atrophy or regression of the original connection to the main liver, ${ }^{4}$ migration or displacement of a portion of the cranial part (Pars hepatica) of the liver bud to other sites, ${ }^{6}$ dorsal budding of hepatic tissue before the closing of the pleuroperitoneal canal (may explain how EL develops in the thoracic cavity such as esophagus, pericardium, intra pleural or extra pleural), ${ }^{7}$ trapping of hepatocyte-destined mesenchyma in different areas ${ }^{8}$ and entrapment of nests of cells in the region of the foregut following closure of the diaphragm or umbilical ring. ${ }^{9}$

The close relationship of the developing hepatic parenchyma cell cords to the pars cystica and early fetal duodenum may explain why ectopic hepatic tissue could be found in the wall of the gallbladder, the gastrohepatic ligament, the umbilical cord, the adrenal glands, the diaphragm, the pancreas, the pylorus, and the splenic capsule if a portion of the pars hepatica is displaced.

Although the EL is usually attached to the serosa of the gallbladder or lies within its wall, it can also occur in the gallbladder lumen. ${ }^{4}$

Ectopic liver is sometimes associated with other congenital anomalies such as biliary atresia, ${ }^{9}$ agenesis of the caudate lobe, omphalocele, bile duct cyst ${ }^{10}$ or cardiac and conotruncal anomalies, ${ }^{11}$ but not when the heterotrophic tissue is in the gallbladder.

Detection of EL tissue before surgical intervention or autopsies by means of imaging studies is rare. 4,12 This may be due to the small size of most EL, the lack of awareness of this unusual condition among radiologists, difficulty interpreting the imaging and the frequent lack of symptoms.

Symptoms occur rarely, and ectopic livers have been reported $1,4,13$ to cause recurrent abdominal pain due to torsion, hemorrhagic necrosis, compression of adjacent organs, intra peritoneal bleeding as well as obstruction of the esophagus, portal vein, and neonatal gastric outlet.

The histological architecture of the ectopic tissue resembles normal liver, with regular lobules, central veins, and normal portal areas in most cases. ${ }^{7}$

In our case, ectopic liver tissue has its own mesentery and contains normal tissue elements, i.e. normal hepatocytes, arteries, veins, bile ductules with no disturbance in architecture. Drainage into the gallbladder seems likely because of the absence of bile duct dilatation or cholestasis.. Thus ectopic liver in the gall bladder can undergo fatty changes, hemosiderosis, cholestasis, cirrhosis, hepatitis or malignant degeneration to hepatocellular carcinoma. ${ }^{2}$

Ectopic liver tissue is at increased risk of developing hepatocellular carcinoma. However when compared to other locations, ectopic liver tissue attached to gall bladder is least likely to undergo malignant transformation because it is an anomaly occurring later during late embryogenesis and is therefore well differentiated. This is supported by the fact that Arakawa et al., (1999) in their study revealed that only one out of 33 cases of ectopic liver tissue attached to gall bladder develop cancer as compared to 22 cases out of 48 cases of ectopic liver attached to other locations develop hepatocellular carcinoma. ${ }^{14}$

CONCLUSION: A case of Ectopic liver tissue on the wall of gall bladder in a 45 years old woman, which was detected incidentally during laparoscopic cholecystectomy for cholelithiasis, has been reported. The lesion we have reported is completely isolated from main liver tissue, but it has got connection with the gall bladder lumen, as revealed by the presence of its own mesentery and normal liver tissue. 
Ectopic liver is usually an incidental finding during a laparoscopy, laparotomy or autopsy performed for unrelated reasons, most commonly for diseases of the gallbladder. Hepatobiliary Imino- Diacetic Acid (HIDA) scan, besides ultrasonography and computerized tomography, may be helpful in diagnosis. Colour Doppler ultrasound or angiography may demonstrate a feeding vessel.

\section{REFERENCES:}

1. Collan Y, Hakkiluoto A, Hastgacka J. Ectopic liver. Ann Chir Gynaecol 1978; 67: 27-29.

2. Martinez CAR, Júnior HCR, Rodrigues MR, Satoc DT, Brunialti CV and Palma RT (2013). Gallbladder-associated ectopic liver: A rare finding during a laparoscopic cholecystectomy. International Journal of Surgery Case Reports 4 312- 15.

3. Eiserth P. Beitrage zur Kenntnis der Nebenlebern. Virchows Arch A Pathol Anat Histopathol 1940; 307: 307-313.

4. Watanabe M, Matsura T, Takatori Y. Five cases of ectopic liver and a case of accessory lobe of the liver. Endoscopy 1989; 21: 39-42.

5. Moore KL. The developing human: clinically oriented embryology 2nd ed. Philadelphia: Saunders, 1977.

6. Tejada E, Danielson C. Ectopic or heterotopic liver (Choristoma) associated with the gallbladder. Arch Pathol Lab Med 1989; 113: 950-2.

7. Hamdani SD, Baron RL. Ectopic liver simulating a mass in the gallbladder wall: Imaging findings. AJR 1994; 162: 647-8.

8. Ferro F, Lais A, Boldrini R, De Peppo F, Federici G, Bosman C. Hepatogonadal fusion. J Pediatr Surg 1996; 31: 435-6.

9. Park WH, Choi SO, Lee SS, Randolph JG. Ectopic umbilical liver in conjunction with biliary atresia: Uncommon association. J Pediatr Surg 1991; 26: 219-22.

10. Asada K, Onji S, Yamashita Y et al. Ectopic liver observed by peritoneoscopy; report of a case. Gastroenterol Endosc 1982; 24:309-12.

11. Shapiro JL, Metlay LA. heterotopic supradiphragmatic liver formation in association with congenital cardiac anomalies. Arch Pathol Lab Med 1991; 115: 238-40.

12. Catani M, De Milito R, Romagnoli F, et al. Ectopic liver nodules: a rare finding during cholecystectomy. Giornale di Chirurgia 2011; 32: 255-8.

13. Matley PJ, Rode H, Cywes S. Portal vein obstruction by ectopic liver tissue. J Pediatr Surg 1989 ; 24: 1163-1164.

14. Arakawa M, Kimura Y, Sakata K, Kubo Y, Fukushima T and Okuda K (1999). Propensity of ectopic liver to hepatocarcinogenesis: case reports and a review of the literature. Hepatology 29(1) 57-61. 


\section{CASE REPORT}

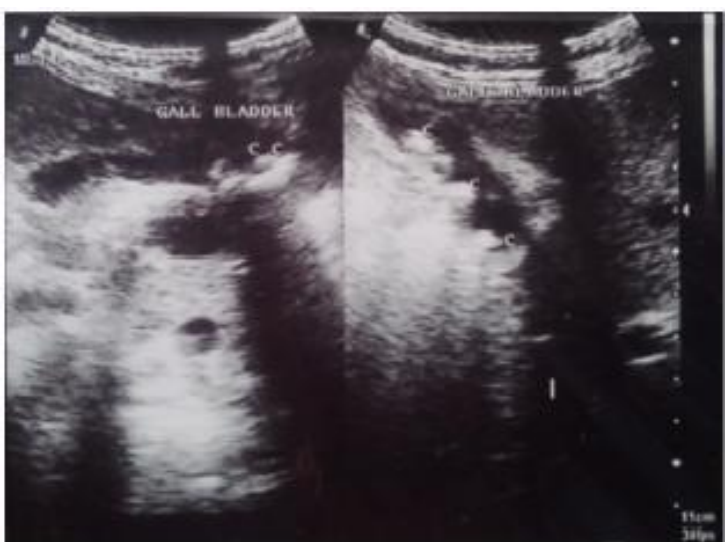

Figure 1. Ultrasonography Picture showing cholelithiasis

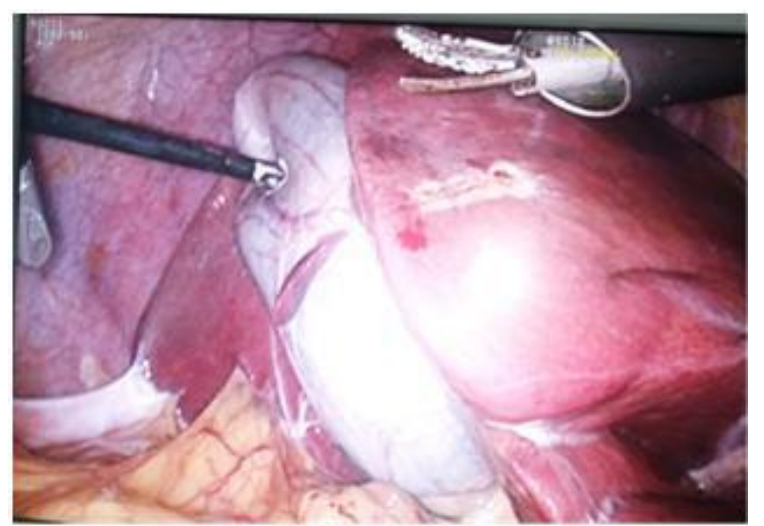

Figure 2. Ectopic Liver in Gall Bladder seen during Laparoscopic Cholecystectomy

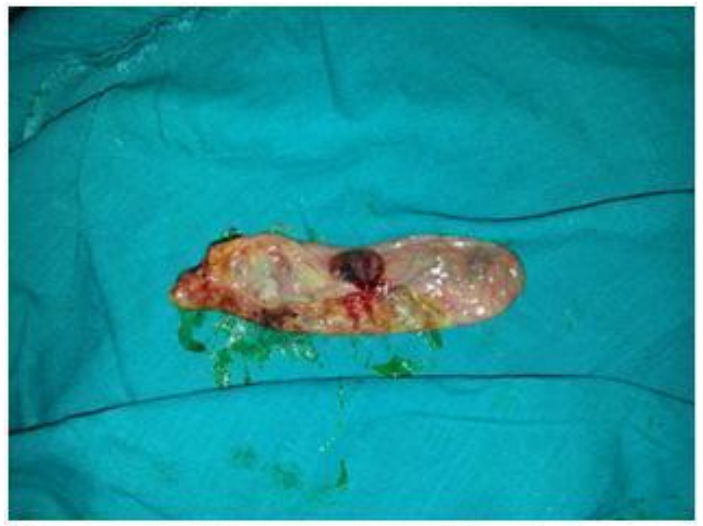

Figure 3. Gall Bladder Specimen showing Ectopic Liver

\section{AUTHORS:}

1. Abhilash S.

2. Karthik K.

3. Keisham Lokendra Singh

4. S. Ranita Devi

5. G. S. Moirangthem

\section{PARTICULARS OF CONTRIBUTORS:}

1. Junior Resident, Department of Surgery, RIMS, Imphal.

2. Junior Resident, Department of Surgery, RIMS, Imphal.

3. Senior Resident, Department of Surgery, RIMS, Imphal.

4. Professor, Department of Surgery, RIMS, Imphal.
5. Professor and HOD, Department of Surgery and MAS Unit, RIMS, Imphal.

\section{NAME ADDRESS EMAIL ID OF THE} CORRESPONDING AUTHOR:

Keisham Lokendra Singh,

Sagolband Tera Khuraijam,

Leikai, Imphal-795001,

Manipur.

E-mail: drkeisham@hotmail.com

Date of Submission: 07/01/2015.

Date of Peer Review: 08/01/2015.

Date of Acceptance: 19/01/2015.

Date of Publishing: 29/01/2015. 